\title{
Penerapan Logika Fuzzy pada Sistem Cerdas
}

\author{
Bayu Setia \\ STMIK Tunas Bangsa \\ Bandar Lampung \\ bsetia@,gmail.com
}

\author{
Agus Ramadan \\ STMIK Tunas Bangsa \\ Bandar lampung \\ ramadan87@,yahoo.co.id
}

\begin{abstract}
Abstrak- Logika fuzzy telah dikembangkan sejak lama dan digunakan di banyak bidang oleh para ahli dan insinyur. Pada awalnya, logika fuzzy digunakan di beberapa bidang, hanya, seperti penyakit, mendiagnosis sistem (dalam madicine); pemodelan sistem pemasaran, penelitian operasi (pada ekonomi); kontrol kualitas air, prediksi gempa, klasifikasi dan pengenalan pola. Penggunaan logika fuzzy dalam bidang sistem daya juga telah dilakukan, seperti analisis probabilitas, prediksi dan pengendalian beban, identifikasi kesalahan generator dan penjadwalan, pemeliharaan generator. Makalah ini menjelaskan penerapan logika fuzzy di bidang sistem cerdas.

Kata Kunci : Fuzzy, Kecerdasan Buatan

Article history:

Received: 12 March 2019 Received in revised form: 17 March 2019 Accepted: 25 April 2019 Available online: April 2019
\end{abstract}

\section{Pendahuluan}

Penerapan teknologi saat ini semakin merata disegala aspek, Otomatisasi menjadi satu hal yang paling sering dikembangkan. Kecerdasan Buatan (Artificial Intelligence atau AI) didefinisikan sebagai kecerdasan yang ditunjukkan oleh suatu entitas buatan. Sistem seperti ini umumnya dianggap komputer. Kecerdasan diciptakan dan dimasukkan ke dalam suatu mesin (komputer) agar dapat melakukan pekerjaan seperti yang dapat dilakukan manusia. Beberapa macam bidang yang menggunakan kecerdasan buatan antara lain sistem pakar, permainan komputer (games), logika fuzzy, jaringan syaraf tiruan dan robotika. Logika Fuzzy adalah peningkatan dari logika Boolean yang mengenalkan konsep kebenaran sebagian. Dimana logika klasik menyatakan bahwa segala hal dapat diekspresikan dalam istilah binary ( 0 atau 1 , hitam atau putih, ya atau tidak), logika fuzzy menggantikan kebenaran boolean dengan tingkat kebenaran. Orang yang belum pernah mengenal logika fuzzy pasti akan mengira bahwa logika fuzzy adalah sesuatu yang amat rumit dan tidak menyenangkan. Namun, sekali seseorang mulai mengenalnya, ia pasti akan sangat tertarik dan akan menjadi pendatang baru untuk ikut serta mempelajari logika fuzzy. Logika fuzzy dikatakan sebagai logika baru yang lama, sebab ilmu tentang logika fuzzy modern dan metodis baru ditemukan beberapa tahun yang lalu, padahal sebenarnya konsep tentang logika fuzzy itu sendiri sudah ada pada diri kita sejak lama.

\section{Landasan Teori}

\subsection{Sistem Cerdas}

Berikut beberapa konsep dari sistem cerdas:

1. Sistem Pakar. Sistem pakar merupakan pengetahuan manusia dalam komputer untuk memecahkan suatu permasalahan dan dikerjakan oleh seorang pakarnya, contoh : Dokter. Mereka hanya memecahkan permasalahan sesuai 
dengan pekerjaannya atau sesuatu yang sudah dikuasai. Sistem pakar ini sendiri memiliki 4 bagian, yaitu User Interface, Knowledge Base, Inference Engine, dan Development Engine. Lalu ada jenis-jenis pada sistem pakar yaitu sebagai berikut Interpretasi, Prediksi, Diagnosis, Design, Planning, Monitoring, Debugging, Reparasi, Instruction, dan terakhir Control.

2. Decision Support System (DSS) atau disebut juga dengan sistem pendukung keputusan yang merupakan serangkaian kelas tertentu dari sistem informasi terkomputerisasi yang mendukung pengambilan keputusan bisnis dan organisasi. Informasi yang bisa dikumpulan dengan aplikasi DSS ialah Kita dapat mengakses semua aset informasi terkini, ada data legasi dan relasional, kumpulan data, gudang data, dan lain sebagainya. Angka-angka penjualan antara periode dengan periode lainnya. Angka pendapatan yang dapat diperkirakan, namun ada konsekuesinya pada pilihan pengambilan keputusan yang berbeda dengan pengalaman dalam suatu konteks yang dirinci ulang.

3. Pengolahan Bahasa Alami (Natural Language Processing) dengan adanya ini diharapkan sekali user dapat berkomunikasi dengan komputernya menggunakan bahasa sehari-hari dan dapat dengan nyaman menyelesaikan permasalahannya di komputer.

4. Pengenalan Ucapan (Speech Recognition) dengan adanya ini diharapkan user dapat berkomunikasi dengan komputernya hanya dengan media suara saja.

5. Robotika \& Sistem sensor. Robot adalah sebuah manipulator yang terkendali, multifungsi, dan mampu diprogram untuk bergerak dalam tiga sumbu atau lebih, yang tetap berada di tempat atau bergerak untuk digunakan dalam aplikasi otomasi industri. Sedangkan sensor tiruan dari indra pada makhluk hidup. Sensor ini berfungsi sebagai komponen yang membuat robot bisa merespon lingkungan sekitarnya.

6. Computer Vision yang dapat menginterpretasikan gambar atau objek melalui komputer sesuai yang diinginkan oleh usernya. Konsep ketujuh adalah Intelligent Computer-aided Instruction yang dipakai untuk melatih dan mengajar dan sangat bermanfaat bagi user. Konsep yang terakhir adalah Game Playing yang tidak diragukan lagi kehebatannya pada interaksi manusia dengan teknologi, terutama para gamers yang selalu berinteraksi dengan komputer.

\subsection{Logika Fuzzy}

Fuzzy secara bahasa diartikan sebagai kabur atau samar samar. Suatu nilai dapat bernilai besar atau salah secara bersamaan. Dalam fuzzy dikenal derajat keanggotaan yang memiliki rentang nilai 0 (nol) hingga 1 (satu). Berbeda dengan himpunan tegas yang memiliki nilai 1 atau 0 (ya atau tidak). Logika Fuzzy merupakan seuatu logika yang memiliki nilai kekaburan atau kesamaran (fuzzyness) antara benar atau salah. Dalam teori logika fuzzy suatu nilai bias bernilai benar atau salah secara bersama. Namun berapa besar keberadaan dan kesalahan suatu tergantung pada bobot keanggotaan yang dimilikinya. Logika fuzzy memliki derajat keanggotaan dalam rentang 0 hingga 1 . Berbeda dengan logika digital yang hanya memiliki dua nilai 1 atau 0. Logika fuzzy digunakan untuk menterjemahkan suatu besaran yang diekspresikan menggunakan bahasa (linguistic), misalkan besaran kecepatan laju kendaraan yang diekspresikan dengan pelan, agak cepat, cepat, dan sangat cepat. Dan logika fuzzy menunjukan sejauh mana suatu nilai itu benar dan sejauh mana suatu nilai 
itu salah. Tidak seperti logika klasik (scrisp)/tegas, suatu nilai hanya mempunyai 2 kemungkinan yaitu merupakan suatu anggota himpunan atau tidak. Derajat keanggotaan 0 (nol) artinya nilai bukan merupakan anggota himpunan dan 1 (satu) berarti nilai tersebut adalah anggota himpunan.

Logika fuzzy adalah suatu cara yang tepat untuk memetakan suatu ruang input kedalam suatu ruang output, mempunyai nilai kontinyu. Fuzzy dinyatakan dalam derajat dari suatu keanggotaan dan derajat dari kebenaran. Oleh sebab itu sesuatu dapat dikatakan sebagian benar dan sebagian salah pada waktu yang sama (Kusumadewi. 2004) Logika Fuzzy memungkinkan nilai keanggotaan antara 0 dan 1, tingkat keabuan dan juga hitam dan putih, dan dalam bentuk linguistik, konsep tidak pasti seperti "sedikit", "lumayan" dan "sangat" (Zadeh 1965). Kelebihan dari teori logika fuzzy adalah kemampuan dalam proses penalaran secara bahasa (linguistic reasoning). Sehingga dalam perancangannya tidak memerlukan persamaan matematik dari objek yang akan dikendalikan.

Sejarah Logika FuzzyFuzzy Set pertama kali diperkenalkan oleh Prof. Lotfi Zadeh, 1965 orang Iran yang menjadi guru besar di University of California at Berkeley dalam papernya yang monumental "Fuzzy Set". Dalam paper tersebut dipaparkan ide dasar fuzzy set yang meliputi inclusion, union, intersection, complement, relation dan convexity. Lotfi Zadeh mengatakan Integrasi Logika Fuzzy kedalam sistem informasi dan rekayasa proses adalah menghasilkan aplikasi seperti sistem kontrol, alat alat rumah tangga, dan sistem pengambil keputusan yang lebih fleksibel, mantap, dan canggih dibandingkan dengan sistem konvensional. Dalam hal ini kami dapat mengatakan bahwa logika fuzzy memimpin dalam pengembangan kecerdasan mesin yang lebih tinggi (machine Intelligency Quotient / MIQ ) Produk produk berikut telah menggunakan logika fuzzy dalam alat alat rumah tangga seperti mesin cuci, video dan kamera refleksi lensa tunggal, pendingin ruangan, oven microwave, dan banyak sistem diagnosa mandiri. Fuzzy Logic merupakan kecerdasan buatan yang pertama kali dipublikasikan oleh Prof.Dr. Lotfi Zadeh yang berasal dari Pakistan. Melalui fuzzy logic ini sistem dapat membuat keputusan sendiri dan terkesan seperti memiliki perasaan, karena memiliki keputusan lain selain iya (logika 1) dan tidak (logika 0). Oleh karena itu fuzzy logic sangat berbeda jauh dari alur logaritma pemrograman.

\subsection{Perangkat Lunak Sistem Cerdas}

Perangkat lunak kecerdasan buatan membuat baik penggunaan fuzzy logic di daerah yang tidak memiliki aturan yang jelas atau nilai-nilai absolut. Dalam setiap kasus di mana jawabannya akan "kadang-kadang" atau "mungkin," logika fuzzy sangat membantu.

Kredit - Fuzzy logic dapat digunakan untuk membantu mengevaluasi kredit peminjam. Kadang-kadang, peminjam yang memiliki skor kredit yang rendah harus diberikan kredit, jika mereka memiliki atribut positif lainnya, seperti pendapatan yang stabil dan aset yang cukup. Baca lebih lanjut di Aplikasi Logika Fuzzy untuk Perbankan dan Pinjaman .

Robotika - Fuzzy logic adalah sangat berguna dalam membantu robot memutuskan apa yang harus dilakukan dengan input sensorik. Setiap jenis kontak akan memerlukan respon yang berbeda, tergantung pada sejumlah factors.Read lebih lanjut tentang peran AI dalam teknologi robot saat ini, di Robotika dan Kecerdasan Buatan Campurkan dalam Perang Robot 
modern .

Business Intelligence - aplikasi Fuzzy logic dapat membantu eksekutif mengevaluasi keputusan berdasarkan sejumlah kriteria. Aplikasi logika fuzzy dapat digunakan untuk berbagai solusi AI. Jenis algoritma pengolahan informasi bisa sangat sulit untuk membuat, tetapi hasilnya sangat besar.

\section{Hasil Pembahasan}

Logika Fuzzy, yang dalam bahasa Indonesia dapat diartikan sebagai Logika Kabur atau Logika Samar, dapat dikatakan sebagai "logika baru yang sudah lama". Hal ini karena ilmu tentang logika fuzzy secara modern dan metodis ditemukan pada tahun 1965, namun konsep logika fuzzy sudah melekat pada diri manusia, sejak manusia ada. Konsep logika fuzzy dapat dengan mudah kita temukan pada perilaku manusia dalam kesehariannya, misalnya:

- Pedal gas kendaraan akan kita tekan dengan tekanan tertentu sesuai kecepatan yang kita inginkan. (Berapa besar tekanan yang kita berikan?)

- Kita cenderung memberi hadiah kepada seseorang dengan nilai tertentu sesuai dengan manfaat orang tersebut kepada kita. (Berapa besar nilai hadiah yang akan kita berikan?) Kita akan marah kepada orang yang merugikan kita. (Berapa besar kemarahan kita?)Kita tidak bisa menjawab dengan pasti pertanyaan-pertanyaan yang muncul di atas. Inilah beberapa contoh kasus yang bisa dijelaskan menggunakan konsep logika fuzzy. Sebagai contoh adalah robot yang menggunakan fuzzy logic dapat memprediksikan kapan ia harus bertindak atau menghindar saat ada halangan di depannya dengan hanya ada peringatan 'awas' dan tanpa ada hitungan matematis yang diberikan oleh user. Sedangkan robot yang menggunakan alogaritma pemrograman konvensional tidak akan dapat memutuskan sendiri untuk menghindar dari halangan yang ada di depannya.

\subsection{Perbedaan Logika Klasik Atau Tegas Dengan Logika Fuzzy}

Terdapat perbedaan mendasar antara logika klasik dengan logika fuzzy. Sebagai contoh, perhatikan dua kalimat perintah berikut ini:

A. Pisahkan kelompok mahasiswa yang memiliki PC dan kelompok mahasiswa yang tidak memiliki PC.

B. Buat kelompok mahasiswa yang pandai dan kelom pok mahasiswa yang bodoh.

Pada Kalimat A, Kita dapat membedakan secara tegas antara kelompok mahasiswa yang memiliki PC dengan kelom pok mahasiswa yang tidak memiliki PC karena ada batasan yang nyata antara kedua kondisi tersebut. Namun Pada Kalimat B, Tidak terdapat batasan yang nyata antara pandai dengan bodoh sehingga kita sulit membedakan mahasiswa yang pandai dengan mahasiswa yang bodoh. Ketidakjelasan Dalam kehidupan sehari-hari, kita sering menemui kondisi ketidakjelasan seperti kalimat B. Ketidakjelasan yang kita alami, dapat kita kelompokkan menjadi:

- Keambiguan (ambiguity), terjadi karena suatu kata/istilah memiliki makna lebih dari satu. Contoh: bulan, maknanya adalah suatu benda langit, namun makna lainnya adalah bagian dari tahun.

- Keacakan (randomness), karena hal yang kita inginkan belum terjadi. Contoh: besok akan hujan.

- Ketidaktepatan (imprecision), disebabkan karena alat atau metode pengukuran yang tidak tepat. Contoh: volume bumi. 
- Ketidakjelasan akibat informasi yang tidak lengkap (incompleteness). Contoh: ada kehidupan di luar angkasa

- Kekaburan semantik, akibat suatu kata/istilah memiliki makna yang tidak dapat didefinisikan secara tegas. Contoh: cantik, pandai, dsb.

Dari kelima kelompok ketidakjelasan tersebut, dapat dikatakan bahwa pembahasan logika fuzzy berada pada kekaburan semantik. Kekaburan semantik pasti ada dalam kehidupan manusia. Bahkan kita sering mengambil keputusan dari kondisi kekaburan semantik. (Kekaburan semantik adalah seperti yang sudah dijelaskan diatas bahwa kata//istilah memiliki makna yang tidak dapat didefinisikan secara tegas. Contoh: cantik, pandai, dsb.

Hal lain yang juga perlu diperhatikan adalah kita (manusia) saat ini sering menggunakan alat bantu, terutama elektronik, untuk membuat suatu keputusan. Penelitian atau pengukuran umumnya memerlukan ketepatan \& kepastian. Sedangkan kondisi lingkungan, mengharuskan kita mengambil keputusan dari kekaburan semantik. Oleh karena itu, perlu bahasa keilmuan baru untuk mengakomodasi kekaburan semantik secara memadai.

\subsection{Aturan Fuzzy IF-THEN}

Metode penalaran secara monoton digunakan sebagai dasar untuk teknik implikasi fuzzy. Meskipun penalaran ini sudah jarang sekali digunakan, namun kadang masih digunakan untuk penskalaan fuzzy. Jika 2 variabel fuzzy direlasikan dengan implikasi sederhana sebagai berikut : If $x$ is $A$ Then $Y$ is $B$ atau $y=f((x, A), B)$ maka sistem fuzzy dapat berjalan tanpa harus melalui komposisi dan dekomposisi fuzzy. Nilai output dapat diestimasi secara langsung dari nilai keanggotaan yang berhubungan dengan antesendennya. Aturan Fuzzy If-Then (atau disebut juga aturan fuzzy, fuzzy implikasi, atau pernyataan kondisional Fuzzy) adalah aturan yang digunakan untuk merumuskan relasi conditional antara 2 atau lebih himpunan fuzzy. Bentuk umum :

If $(\mathrm{X} 1$ is $\mathrm{A} 1) \wedge(\mathrm{X} 2$ is $\mathrm{A} 2) \ldots(\mathrm{Xn}$ is $\mathrm{An})$ Then $\mathrm{Y}$ is $\mathrm{B}$;

xi, yi skalar, dan A, B himpunan Fuzzy Menurut Kusumadewi (2004) Ada 2 fungsi implikasi

yang digunakan yaitu :

1. Min (minimum), fungsi ini akan memotong output (konsekuen) himpunan fuzzy.

2. Dot (product), fungsi ini akan menskala output himpunan fuzzy.

\subsection{Alasan digunakannya Logika Fuzzy}

Ada beberapa alasan mengapa orang menggunakan logika fuzzy, antara lain:

1. Konsep logika fuzzy mudah dimengerti. Konsep matematis yang mendasari penalaran fuzzy sangat sederhana dan mudah dimengerti.

2. Logika fuzzy sangat fleksibel.

3. Logika fuzzy memiliki toleransi terhadap data-data yang tidak tepat.

4. Logika fuzzy mampu memodelkan fungsi-fungsi nonlinear yang sangat kompleks.

5. Logika fuzzy dapat membangun dan mengaplikasikan pengalaman pengalaman para pakar secara langsung tanpa harus melalui proses pelatihan.

6. Logika fuzzy dapat bekerjasama dengan teknikteknik kendali secara konvensional. 
7. Logika fuzzy didasarkan pada bahasa alami

\subsection{Aplikasi yang menggunakan Logika Fuzzy}

1. Manajemen dan pengambilan keputusan, seperti manajemen basisdata yang didasarkan pada logika fuzzy, tata letak pabrik yang didasarkan pada logika fuzzy, sistem pembuat keputusan di militer yang didasarkan pada logika fuzzy, pembuatan games yang didasarkan pada logika fuzzy, dll.

2. Ekonomi, seperti pemodelan fuzzy pada system pemasaran yang kompleks dll.

3. Klasifikasi dan pencocokan pola.

4. Psikologi, seperti logika fuzzy untuk menganalisis kelakuan masyarakat, pencegahan dan investigasi kriminal, dll.

5. Ilmu-ilmu sosial, terutam untuk pemodelan informasi yang tidak pasti.

6. Ilmu lingkungan, seperti kendali kualitas air, prediksi cuaca, dll.

\section{Kesimpulan}

Logika merupakan ilmu yang sangat penting untuk dipelajari, karena merupakan ilmu dasar bagi ilmu ilmu yang lain. Hal ini dapat dilihat dari beberapa contoh yang dipaparkan di atas. Selain itu, logika juga merupakan ilmu untuk berpikir secara sistematis, sehingga mudah dipahami dan dapat dirunut kebenarannya. Logika juga sangat banyak digunakan pada dunia pemrograman, karena hampir setiap bahasa pemrograman menggunakan logika dalam pemecahan permasalahan dan setiap decision-nya. Oleh karena itu, sangat penting kiranya untuk mempelajari logika.

\section{Referensi}

[1] G. Drwal ; M. Sikora, Induction of fuzzy decision rules based upon rough sets theory, 2004 IEEE International Conference on Fuzzy Systems (IEEE Cat. No.04CH37542), 2004

[2] Kusumadewi, Sri. Artificial Intelligence (Teknik dan Aplikasinya) Graha Ilmu, Yogyakarta, 2002.

[3] Kosko, Bart. Neural Network and Fuzzy Systems (A Dynamic Systems Approach to Machine Intelligence), USA Prenticee-Hall,1992, 2015

[4] M. K. Medynskaya, Fuzzy set theory. The concept of fuzzy sets, 2015 XVIII International Conference on Soft Computing and Measurements (SCM)

[5] Suparman, Mengenal Artificial Intelligence, Edisi-1, Andi Offset, Yogyakarta, 1991.

[6] Wang, L. A Course in Fuzzy Systems and Control, Prentice-Hall International, Inc., New Jersey, 1997.

[7] Yuanhua Liang; Bingcheng Yuan, Method for generating fuzzy Petri nets fault diagnosis model based on rough set theory, 2010 2nd International Conference on Future Computer and Communication, 2010

[8] Zimmermann, Fuzzy Set Theory an Its Applications, Second Edition, Kluwer Academic Publishers, 1991. 